\title{
Alexandru Duţu, 1928-1999
}

Alexandru Duțu, who died at the beginning of 1999, was a steadfast animator of southeast European studies and a scholar whose interests cut across disciplinary boundaries and whose writings narrowed the historical distance between east and west. A comparatist in the full sense of the word, he was at home in the French and German as well as the Romanian history of ideas and literature. His favorite period lay between the sixteenth and the early nineteenth century, and he was a pioneer in Romania in the investigation of mentalities.

Born in Bucharest in 1928, Duṭu spent his entire scholarly career in its institutions as student, researcher, teacher, and editor. His university studies reveal how broadly he conceived of culture, which was to be the focus of his life's work. He took degrees (licentia) in law and letters at the University of Bucharest in 1949 and 1956, respectively, and a degree (licenta $\bar{a}$ ) in theology at the Orthodox Theological Institute in 1957. Like a number of his fellow graduates, he belonged to a social category that the communist regime in the $1950 \mathrm{~s}$ had stigmatized, and, consequently, he found his career opportunities severely limited. Between 1951 and 1963, he was a librarian at the Library of the Romanian Academy. Then in 1963, as the regime became more flexible in certain respects, he joined the Institute for Southeast European Studies of the Academy, which had been established in that year and whose director he was to be from 1990 to 1997. He took his doctorate in philology at the University of Bucharest in 1970, and in subsequent years engaged in extensive didactic activity as a professor in the departments of history and of political and administrative sciences at the University of Bucharest and as a lecturer at universities in the United States and western Europe, including the Collège de France in 1995. As an editor he was largely responsible for the publication of two of the leading journals in their respective fieldsthe Revue des études sud-est européenes (1973-1997) and Synthésis, the bulletin of the Romanian Committee for Comparative Literature (1974-1997).

Alexandru Dutu was the author of numerous stimulating and searching volumes that ranged widely over cultures and time periods and challenged established thinking about the forms and the transmission of cultural values. Noteworthy among them are Coordonate ale cullurii româneşi in secolul XVIII (1969), where he analyzes representative Romanian texts of the eighteenth century in order to establish the place of the intellectual in both the far-reaching currents of European thought and the traditional confines of southeast European culture; Umanistiti români şi cultura europeană (1974), which compares the evolution of humanism among the Romanians and in western Europe; Cultura română in civilizatia europeană modernă (1978), a study of resemblances and divergences of cultural forms in the Romanian lands and the west during the Enlightenment; and Humanisme, baroque, lumières - l'exemple roumain (1984), which places Romanian culture and attitudes toward existence in a general European context. In all these works, Dutu suggests that there was a stronger western orientation among Romanian intellectuals before the nineteenth century than has generally been believed. But he never exaggerates the pace at which western cultural values were assimilated. He shows, rather, how tradition remained strong and blended with incoming currents of ideas to give birth to a distinctive new culture.

Not only will Alexandru Duț's writings be missed. His attendance at scholarly meetings promised reasoned argument and subtle wit; his presence at more intimate gatherings of friends and colleagues offered good humor and gentle humanity.

KeITH Hitchins University of Illinois, Urbana-Champaign June 1999 